\title{
The dynamics of God's reign as a hermeneutic key to Jesus' eschatological expectation
}

\begin{tabular}{|c|c|}
\hline \multicolumn{2}{|c|}{$\begin{array}{l}\text { Authors: } \\
\text { Jakub Urbaniak } \\
\text { Elijah Otu }^{1,2}\end{array}$} \\
\hline \multicolumn{2}{|c|}{$\begin{array}{l}\text { Affiliations: } \\
{ }^{1} \text { St Augustine College, } \\
\text { Johannesburg, South Africa }\end{array}$} \\
\hline \multicolumn{2}{|c|}{$\begin{array}{l}{ }^{2} \text { Department of Church } \\
\text { History and Church Polity, } \\
\text { Faculty of Theology, University } \\
\text { of Pretoria, South Africa }\end{array}$} \\
\hline \multicolumn{2}{|c|}{$\begin{array}{l}{ }^{3} \text { St Joseph's Catholic Church, } \\
\text { Mokoena, Katlehong, } \\
\text { Archdiocese of Johannesburg, } \\
\text { South Africa. }\end{array}$} \\
\hline $\begin{array}{l}\text { Project leader } \\
\text { A. Duncan } \\
\text { Project numb }\end{array}$ & er: 02618958 \\
\hline \multicolumn{2}{|c|}{$\begin{array}{l}\text { Description: } \\
\text { Jakub Urbaniak and Elijah } \\
\text { Otu are participating in the } \\
\text { research project, 'Roman } \\
\text { Catholic History in the } \\
\text { modern era: Vatican II and } \\
\text { beyond', directed by Prof. Dr } \\
\text { Graham Duncan, Department } \\
\text { of Church History and Church } \\
\text { Polity, Faculty of Theology, } \\
\text { University of Pretoria. }\end{array}$} \\
\hline \multicolumn{2}{|c|}{$\begin{array}{l}\text { Corresponding author: } \\
\text { Jakub Urbaniak, } \\
\text { jakub-urbaniak@hotmail.com }\end{array}$} \\
\hline \multicolumn{2}{|c|}{$\begin{array}{l}\text { Dates: } \\
\text { Received: } 28 \text { Oct. } 2015 \\
\text { Accepted: } 22 \text { Feb. } 2016 \\
\text { Published: } 05 \text { Aug. } 2016\end{array}$} \\
\hline \multicolumn{2}{|c|}{$\begin{array}{l}\text { How to cite this article: } \\
\text { Urbaniak J. \& Otu E., 2016, } \\
\text { 'The Dynamics of God's Reign } \\
\text { as a Hermeneutic Key to } \\
\text { Jesus' Eschatological } \\
\text { Expectation', HTS Teologiese } \\
\text { Studies/Theological Studies } \\
\text { 72(1), a3232. http://dx.doi. } \\
\text { org/10.4102/hts.v72i1.3232 }\end{array}$} \\
\hline \multicolumn{2}{|l|}{ Read online: } \\
\hline ㅁifin: & $\begin{array}{l}\text { Scan this QR } \\
\text { code with your } \\
\text { smart phone or } \\
\text { mobile device } \\
\text { to read online. }\end{array}$ \\
\hline
\end{tabular}

With this study, we seek to contribute to the theological discussion regarding the nature and the meaning of the Christian eschaton. We will argue that the dynamics of God's reign provide a hermeneutic key to Jesus' 'eschatological expectation'. It is not possible to grasp the full meaning of Jesus' urgent expectation of the end unless one realises that God's action is always eschatological. That is to say, right from creation, God is always acting in history in an eschatological way, though only in Jesus does this action reach its ultimate goal. By critically examining the multifaceted views of selected contemporary theologians, we will suggest that Jesus' eschatological expectation may be adequately interpreted only in light of God's 'eschatological reign'. In this context, the tension between the already present and not yet fully realised dimensions of God's reign appears as a promising hermeneutic key to Jesus' teaching in general and his eschatological expectation in particular. The article consists of two sections. Firstly, we will give a brief account of the dynamics of God's reign, interpreted according to the 'middle way' between consistent and realised eschatology. In the second part, our focus will be on the eschatological expectation: its development in the Jewish tradition; on how Jesus applied, or rather re-appropriated, it in his mission; and whether or not his emphasis on the imminence of an eschaton was a result of him being mistaken.

It still looks as though a monstrous illusion lies at the basis of the whole mission of Jesus, the illusion of something immediately impending which actually never has come to pass. (Dibelius 1949:70)

If the reign of God is still not present in its full abundance, it is not because God is holding it back but because we have not yet grasped it ... Here, then, we are constantly living in a state of imminent expectation, in a space in which God's promises earnestly seek fulfilment. (Lohfink 2014:15, 16)

In Jesus and Judaism, Sanders (1985:222) maintains that Jewish eschatological expectation stands at the beginning as well as at the conclusion of Jesus' career. Without a doubt, Jesus challenged many religious views and customs characteristic of first-century Judaism. Nonetheless, in culturalreligious terms he was a child of his time, and thereby it is reasonable to posit that the religious climate prevailing in his environment shaped his preaching and perception of the reign of God; ${ }^{1}$ his eschatological proclamation; and, in particular, his imminent expectation of the end (Schwarz 2000:61, 68). However, what requires deeper examination and clarification is the correlation between the reign of God and the urgency of the end, which Jesus himself identified with the coming (the second coming, one should add) of the Son of Man, as envisioned in Matthew 10:23, '... you will not have gone through all the towns of Israel before the Son of Man comes', and in Matthew 24:34, '... this generation will not pass away until all these things have taken place'. ${ }^{2}$ Whether these two motifs can be reconciled as constitutive of the overall perspective in Jesus' eschatological expectation will be investigated in this article.

The problem of Jesus' 'eschatological mistake', be it real or apparent, continues to attract the attention of theologians (e.g. Lohfink 2014:1-36; Patterson 2010). We believe that Jesus' expectation of an imminent end calls for a fresh and novel interpretation of the dynamics of God's reign. Moreover, we will argue that such an interpretation may provide a hermeneutic key not only to

1.The term 'reign of God' (alternatively, 'God's reign') is preferred in this study to the 'Kingdom of God' for a twofold reason: linguistic and theological. Firstly, it is more gender-inclusive. Secondly, it better reflects the dynamic nature of God's rule ('kingdom' may connote both God's rule and the dominion over which God is sovereign; thus, unlike reign, it can be understood in a 'static' way).
2.See also Mark 13:29; 30 and Luke 21:31-32. All scripture references are quoted according to the NRSV Catholic Edition.

Note: Dr Jakub Urbaniak (PhD: UBO Brest; DTh/MTh: UAM Poznan) came to South Africa in 2010 from Poland. He is a research fellow at the Faculty of Theology, University of the Free State, and a Senior Lecturer in Systematic Theology and Philosophy of Religion at St Augustine College, a Catholic University in Johannesburg. He is also an extraordinary lecturer at the University of Pretoria, where he did his postdoctoral fellowship (2013-2014). Currently, in his research he focuses on the category of 'life' as a hermeneutic key to bridging his postdoctoral fellowship (2013-2014). Currently, in his research he focuses on the category of 'life' as a hermeneutic key
the gap between ecological theologies and contextual/liberation theologies, with their various social-political emphases.

Fr Elijah Otu is a Catholic priest of the Missionary Society of St Paul. In 2015 he graduated from St Augustine College of South Africa. His master's thesis, written under the supervision of Dr Urbaniak, focused on Jesus' eschatological expectation as interpreted through the lens of God's 'eschatological reign'. Currently, he ministers at St Joseph's Catholic Church at Mokoena, Katlehong.

Copyright: @ 2016 . The Authors. Licensee: AOSIS. This work is licensed under the Creative Commons Attribution License. 
his eschatological expectation, but also to that held by the church ever since. ${ }^{3}$

By critically examining the multifaceted views of the selected contemporary theologians, we will suggest that Jesus' eschatological expectation may be adequately interpreted only in light of God's eschatological reign. In other words, it is not possible to grasp the full meaning of Jesus' urgent expectation of the end unless one realises that God's action is always eschatological. That is to say, right from creation, God is always acting in history in an eschatological way, though it is only in Jesus that this action reaches its ultimate goal (Lohfink 2014:15). Thus the tension between the already present and not yet fully realised dimensions of God's reign appears as a promising hermeneutic key to Jesus' teaching in general and his eschatological expectation in particular.

Regarding the theoretical framework, this study will be undertaken in the light of Avery Dulles' hermeneutical theology (Dulles 1979). Following Dulles' principles, we will seek to interpret the dynamics of God's reign in such a way as to arrive at a hermeneutical key to Jesus' eschatological expectation, wherein the product of our interpretation will be the result of a dialectical relationship between the biblical text, on the one hand, and the analogical imagination of the interpreters (us as theologians) on the other hand (1979:20, 23).

In this research, both historical-critical method and positive theological hermeneutics are employed. A qualitative analysis of the historical Jesus study attempts to, as it were, strip Jesus of the doctrinal layers said to be tied to him by the early church (Bock 2011:5). However, in our analysis this is not considered the end in itself. Rather, we intend to refer to the findings of the biblical exegesis based on the historical-critical method in order to reinterpret and re-evaluate the theological meanings that Christian theological tradition assigned to Jesus' eschatological expectation through the lens of his Kingdom proclamation. As our study seeks to show the correlation between the dynamics of God's reign and the eschatological expectation of Jesus, significant consideration is given to the hermeneutic methodology. We recognise that Jesus is not only a historical, contextually grounded person, but also a theological figure. Part of our quest is, therefore, to understand Jesus as the agent of God's reign (or God's eschatological representative) and his mission and ministry as God's self-revelation. Thus, methodology suited to historical Jesus study must be accompanied and complemented, so to speak, by a positive theological interpretation (Bock 2011:6).

This article consists of three sections. Firstly, we give a brief account of the dynamics of God's reign interpreted according to the middle way between consistent and realised eschatology. In the second part, our focus is on the eschatological expectation: its development in the Jewish tradition; on how Jesus applied, or rather re-appropriated, this expectation in his mission; and whether or not his

3.As co-authors of this study, we have naturally divided our duties, with each of us focusing on different aspects of the topic. However, the core argument has been focusing on different aspects of the topic. However, the core argument has been
developed by both of us, through a stimulating dialogue. This should be separated developed by
as the Note. emphasis on the imminence of an eschaton was a result of him being mistaken. The final section is devoted to the reflection on the universality of eschatological expectation, conceived of not only with regard to Jesus himself, but also with regard to an ecclesial experience ever after, as well as the consideration of patience and hope as theological categories.

\section{God's reign: A middle way between consistent and realised eschatology}

The tension between the present and future reality of the reign of God already posed a great theological concern during the time of Jesus, as attested to by the curiosity of the Pharisees:

Once Jesus was asked by the Pharisees when the kingdom of God was coming, and he answered, 'The kingdom of God is not coming with things that can be observed; nor will they say, "Look, here it is!" or "There it is!" For the kingdom of God is among you'. (Lk 17:20; authors's own italics; cf. also Keener 2009:199; Patterson 2010:68)

Luke 11:20 and Matthew 12:28 seem to support the thesis that Jesus understood God's reign as something that took place in his actions during his public ministry: 'But if it is by the finger / Spirit of God that I cast out the demons, then the Kingdom of God has come to you'. The text that further supports the futurity of the reign of God is the Lord's Prayer (Mt 6:9-13; Lk 11:2-4), which most scholars accept as authentic (Keener 2009:198). As Robinson suggests, Jesus' proclamation of the good news focused on the coming of God's reign was, first of all, 'his rhetoric for talking about religious experience, not a doctrine about last things' (Robinson 2011:3220). Küng offers a similar insight when he argues that Jesus' sayings about the future 'must not be understood as apocalyptic information, but as eschatological promise' (Küng 1977:221; authors's own italics).

However, many other sayings, both in the gospels and the $Q$ source (from the lips of Jesus himself or attributed to him) attest to Jesus' futurist understanding of God's reign, almost always in conjunction with the expectation of its imminent coming, to mention only Mark 1:9, 'Truly I tell you, there are some standing here who will not taste death until they see that the kingdom of God has come with power', or Mark 14:25, 'Truly I tell you, I will never again drink of the fruit of the vine until that day when I drink it new in the kingdom of God'.

Ultimately, it was precisely this ambiguity of the biblical accounts of the nature of God's reign that gave rise to the emerging of the schools of consistent eschatology and realised eschatology. A sharply defined theological controversy regarding the nature of God's reign began with the publication, in 1892, of a revolutionary book by a liberal Protestant theologian, Johannes Weiss, titled Jesus' proclamation of the Kingdom of God. In his book, Weiss considers the reign of God not

as an ethical or political conception that might give relevance to the message of Jesus, but as a product of eschatological and apocalyptic fantasies that are totally alien to the modern outlook. (Macquarrie 1990:274) 
According to Weiss (1971:129-131), Jesus generally believed that the messianic time was imminent, but his vision of Satan's defeat was so strong that he sometimes declared that God's reign had already dawned. Though originally Jesus expected to see the establishment of God's reign during his lifetime, he eventually became convinced it would only come after his death; and then he expected to return within the lifetime of the generation that rejected him. Furthermore, Weiss postulated that Jesus was not the founder of God's reign, but simply proclaimed its coming. The reign can be brought in solely by God's supernatural power, and it does not depend on human efforts, least of all on any political revolution or evolution (Weiss 1971:82). Albert Schweitzer's The quest for the Historical Jesus, first published in 1906, became another programmatic work of the consistent eschatologists. Schweitzer saw Jesus as a failed and mistaken proclaimer, for the central motif of his teaching ministry - the imminent coming of God's reign - proved to be but an illusion (Schweitzer 1998:233ff; cf. also Fuellenbach 2006:189; Sullivan 1988:3).

All similar theological hypotheses regarding the otherworldly and futurist nature of the reign of God that have emerged ever since fall under the label of 'consistent (or consequent) eschatology' (German konsequente Eschatologie). Generally, this view holds that God's reign in Jesus' preaching is considered as a reality expected to come within the imminent future. Therefore, statements that refer to the present reality of God's reign are usually interpreted as prophetic visions: The future events are presented with such vividness that the distance separating them from the present is radically shortened, and as a result their occurrence seems immediate (Fuellenbach 2006:189).

Following upon the interest that the above interpretation of God's reign generated among theologians, an opposing school soon emerged in defence of a different account of God's reign. According to these scholars, the reign of God had been, in essence, already realised in the person and entire ministry of Jesus. This view, popularised mainly by C.H. Dodd in his book The Parable of the Kingdom, first published in 1935, came to be known as 'realised eschatology'. In Dodd's own words:

Here then is the fixed point from which our interpretation of the teaching regarding the kingdom of God must start. It represents the ministry of Jesus as 'realised eschatology', that is to say, as the impact upon this world of the 'powers of the world to come' in a series of events, unprecedented and unrepeatable, now in actual process. (Dodd 1961:41)

Some hold that Dodd's work served as an apologia to an embarrassed world following the radical views of consistent eschatologists (Sullivan 1988:4, 8). According to the interpretation propounded by the realised eschatologists, not only with regard to the Incarnation, but also with regard to God's reign, history has become the vehicle of the eternal. This world has become the scene of a divine drama in which eternal issues are laid bare. The parables in particular present the reign of God as an event that is happening now, in the present experience of the people. The healings and mighty works are not just pointers to the future, but the real signs of God's reign in the midst of the world (Fuellenbach 2006:190). In this context, it is not hard to see why many realised eschatologists consider the scriptural references to God's reign as a future reality to be early Christian interpolations, thus not authentic to Jesus. Dodd himself holds that it is no doubt possible to take the view that the predictions which we find in the Gospels are no more than a reflection of the experience of the early Church within which the tradition was founded' (1961:41-42).

Without doubt, both schools raise several valid points, and both of them can support (at least some of) their claims referring to the biblical material. Deist and Plessis (1981:134-135) notice that when the entire New Testament is considered, it yields overwhelming evidence of the diversity as far as the dynamic nature of God's reign (at once present and future) is concerned. As the above biblical references show, in the synoptic gospels one finds mention of both, with the emphasis on the futurity. In addition, in Paul references to both facets are present (cf. Rm 14:17 and 1 Cor 6:9). In John's writings, on the other hand, statements on the present reality dominate (cf. Jn 4:23; Jn 4:35-38; Jn 3:2-6).

In light of the ambiguity of the biblical texts at hand (or their hermeneutic potential, to put it in positive terms), in the few past decades a growing number of scholars have appeared who hold that, in fact, the two views in question consistent and realised eschatologies - do not have to be seen as exclusive. Because both references, to the present and to the future nature of God's reign, are extant in the entire ministry of Jesus, it seems justifiable, indeed necessary, to aim at theological reconciliation or even synthesis of the two interpretations under consideration. Thus, a third school has emerged that attempts to mediate both views (Kasper 1976; Kreplin 2011; Küng 1977; Lohfink 2014; Robinson 2011; Perrin 1963). Unlike the two extreme positions, this school does not have (at least as yet) a formal name, though it seems that 'inaugurated eschatology' - the term used by Robinson (1957:157, 161; cf. also McBrien 1966:44-73) $)^{4}$ - captures a range of options followed by various authors.

It is remarkable, Walter Kasper maintains (1976:76), that the tension between the present and the future belongs to the essence of the reign of God preached by Jesus. God's reign appears in this context as a dynamic concept denoting God's eschatological action in the broadest sense possible (Moltmann 1996:xiv). As Perrin (1963) puts it:

The relationship between the present and the future element in the teaching of Jesus concerning the kingdom should be seen as a relationship between a present in which the long-promised eschatological salvation is known at a personal level and through the ministry of Jesus, and a future in which it will be manifested universally or cosmically through some climactic act of God. (p. 88)

4.The term was first suggested by G. Florovsky (Whitehouse, W.A., 1953, "The Modern Discussion of Eschatology," Scottish Journal of Theology Occasional Papers 2:63-89 [here 76]). 


\section{Similarly Küng observes that:}

Jesus' proclamation is not merely a form of late Jewish apocalyptic, concerned solely with future realities and demanding nothing for the present. But still less is it an interpretation merely of the present and of life here and now, having nothing to do with apocalyptic and an absolute future .... (Küng 1977:221)

Küng is insistent on the fact that, in Jesus' proclamation of God's reign, the 'already-present' and the 'not-yet-fulfilled' belong together, and thus none of the two dimensions can be compromised without losing a dialectic tension that is constitutive of the dynamics of God's reign (Küng 1977, 221ff).

Pondering the same paradox of the 'now' and the 'future' of God's reign, Walter Kasper refers to the difference between the biblical meaning of time and eternity as qualitative, on the one hand, and the philosophical-dialectic interpretation of continuous and homogeneous sequence of days and hours as quantitative, on the other hand (1976:77).

In the same vein, Lohfink (2014:13-15) asserts that God's new world no longer lies in the absolutely to-be-awaited future; indeed, it is coming 'now' through Jesus' salvific action, both in history and through the mission of the church ever since. However, at the same time, the fullness of God's reign is not yet present - it simply cannot be, for there is still unbelief everywhere, which shows that, as a church (and in a broader perspective, as humanity), we have not yet grasped the fullness of God's grace offered through Jesus. In other words, the turning eschatological point has already taken place and, in a sense, takes place continuously. This is paradoxically true in the Christ-event, which encompasses the historical reality of Jesus of Nazareth - his life, death, and life again - as captured by Scripture-in-Tradition and as experienced ever anew in the church through proclamation (word), manifestation (sacrament), and prophetic action (Forsyth 2010:302; Tracy 1981:371-405, 2011:111). Therefore, the 'shining out' of God's reign can be perceived already in the present; it has already entered into the sphere of human experience today (Kreplin 2011:2499). And yet the world has not yet received the fruits of Jesus' salvation in their full abundance, for the only way to receive God's grace fully is to cooperate with it in fulfilling God's will.

\section{Jesus' eschatological expectation: Competing accounts}

In the varied definitions of the term eschatos, literally meaning 'last' (Brown, Donahue, Senior \& Yarbro 2001:1360; Kaiser 2011:iv), the common and underlying characteristic is the distinction between the two biblical ages, found in both the Old and the New Testament: the 'now' and the 'not yet', the latter of which describes the future, the 'last things'.

Jesus was firmly rooted in the traditions and hopes of his people; therefore, it is not surprising that his teachings were understood in terms of the Jewish eschatological expectations. However, he brought a novel dimension to the understanding of the notion of the 'end times'. Some scholars claim that, by doing so, he made an error, the so-called eschatological mistake (Sullivan 1988:63-64, 118; cf. also Deist \& Plessis 1981:132). After briefly looking at Jesus' rootedness in the Jewish apocalyptic tradition, the novelty of Jesus' understanding of an eschaton will be articulated. Then we will examine various theological accounts of Jesus' alleged eschatological mistake, to finally suggest what we consider a radical reinterpretation of his eschatological expectation.

\section{Jesus' rootedness in the Jewish apocalyptic tradition}

The critical-historical Jesus study sheds light on Jesus purely from the human point of view (Bock 2011:5). While bracketing, as it were, divine qualities that early Christians attributed to Jesus, owing to their profound Easter experience, it presents Jesus as a person of his time and culture, deeply rooted in the Jewish faith. Whatever be the limitations inherent in such an approach, its advantage is that it allows us to take due account of Jesus' cultural-religious background. This rootedness undoubtedly shaped Jesus' preaching and perception of God's reign, as well as his imminent expectation of the end (Schwarz 2000:61, 68).

There exists a wide range of opinions among scholars regarding eschatological and apocalyptic sayings attributed to Jesus. Some effectively contend, and some - like the Jesus Seminar scholars - even deny, that Jesus' preaching ministry contained apocalyptic-eschatological character (cf. Allison 2000:267; Funk \& Hoover 1993:1-38; Maloney 1999:12; Sanders 1985:114). Those on the spectrum of a noneschatological Jesus concede that Jesus must have been misunderstood and misinterpreted within a generation. They cite inter alia Luke 19:11ff, the parable of the ten pounds, to support their claims. The apocryphal writing of Thomas is among other writings that seem to disparage eschatological understanding of Jesus' message (Allison 2000:272-273).

In contrast, the data on eschatological judgment and a reversal of the condition of life give a strong indication that Jesus and those around him held strong eschatological hopes and expected the end in no distant time. For instance, the saying 'Blessed are you who are hungry now, for you will be filled' (Lk 6:21) relates to the eschatological reversal akin to Isaiah 60:22: "The least of them shall become a clan and the smallest one a mighty nation'. Equally impressive is the data on the eschatological restoration of Israel that Jesus anticipated, the expectation that was a common hope of the Jews, as demonstrated in the First Testament and the intertestamental literature (Allison 2000:282-285). Several synoptic texts seem to evince Jesus' expectation of a dramatic imminent and transcendent intervention in history that reflects what has been called an 'apocalyptic eschatology' (Brown et al. 2001:1360; Louis 2011:2878-2879).

Allison (2000:299) maintains that in most respects the eschatology of Jesus must be regarded as conventional; that is to say, Jesus' proclamation of the nearness of the consummation, the coming judgment, and the belief in the 
general resurrection of the dead were all handed down to him by his tradition. In this respect, the data on the catastrophes that would precede a better world are all contained in ancient Jewish sources (Sullivan 1988:2-3). In these sources, a graphic picture of birth pangs is predicted. For instance, the rabbis spoke of the 'birth throes of the Messiah':

At that time Michael, the great prince, the protector of your people, shall arise. There shall be a time of anguish, such as has never occurred since the nations first came into existence. (Dn 12:1; cf. also Allison 2000:286)

This is very similar to the material in Mark 13:19: 'For in those days there will be suffering, such as has not been from the beginning of creation that God created until now, no, and never will be'. Intrinsic in Jewish apocalypticism is the phenomenon of catastrophe, and in the sayings attributed to Jesus catastrophic elements are multiply attested to, thus demonstrating Jesus' rootedness in the Jewish apocalyptic tradition in which he was raised (Allison 2000:286-299; Sanders 1985:124).

There is also an overwhelming unanimity among scholars that Jesus took off from where John the Baptist (JBap) left off, having been his disciple, however briefly. As Meyer puts it, 'the beginning of Jesus' public career is inextricably bound up with the public career of John. Both careers were prophetic appeals to the nation' (2005:425). The proclamation of John the Baptist in the wilderness north of the Dead Sea was a warning of judgement and a summons to repentance. His characteristic prophetic appearance alone was taken as a persuasive sign of the truth of his message, a sign of the imminence of the end (2005:425). In the same vein, Patterson (2010:75-76) suggests that Jesus was at one time an admirer of John the Baptist, who preached a message that was at least in part an apocalyptic one. From these two assumptions, Patterson draws a strong inference that Jesus began as one of the many who gave ear to John the Baptist's message of eschatological judgment and expected the apocalypse to come very soon, but became disillusioned when John was brutally killed.

In any case, it seems beyond doubt that Jesus inaugurated his ministry with a proclamation similar in content to that of John the Baptist, except that he did not emphasise the judgment, as John did. Therefore, in speaking of the 'reign of God', Jesus is perceived as an eschatological and apocalyptic prophet, setting himself in the same prophetic line of traditional Judaism to which John the Baptist belonged (Maloney 1999:12-13). And yet the vision of an eschatological reality that emerges from his life, ministry, and especially from his understanding of his own death differs significantly from anything that Jewish apocalypticism was familiar with.

\section{The novelty of Jesus' understanding of an eschaton}

While continuing, to an extent, the eschatological message of John the Baptist, Jesus radically departed from it. He introduced a major shift in emphasis: Whereas John the
Baptist stressed the fearful imminent judgment and punishment of unrepentant sinners, Jesus emphasised the joy of salvation, even now impinging and soon to be fulfilled. This shift is demonstrated in the proclamation of the good news of God's reign, which ultimately formed the major motif of his teaching ministry (Meier 2001:1320). However, what can be deemed the most radical discrepancy between the two of them is the fact that Jesus understood the coming of the new eschatological reality as organically connected with his own ministry and, notably, with his death.

Regarding Jesus' ministry, in particular his table fellowship with the religious outcasts (the 'lost') of Israel, the sinners and tax collectors, demonstrated his understanding of the dynamic nature of God's reign. The eschaton begins and is present, albeit in a limited sense, here and now, with Jesus' association with these people. The message Jesus conveys through this symbolic action is that the eschatological banquet is at hand; a heavenly feast is anticipated in the very meals he shares with the sinners (Meier 2001:1320). In Luke's account, Jesus makes one of the key claims of his entire ministry: God's reign is now. 'Then he began to say to them, "Today this scripture has been fulfilled in your hearing"' (Lk 4:21; authors's own italics). Moreover, Jesus' parables disclose the mystery of God's reign, not only as something yet to be realised, but also as a present reality. ${ }^{5}$ Concretely, 'in Jesus' unassuming talk and action - in his word calling to the poor, hungry, weeping ... the hopeless - there is already the promise of the kingdom where sin, pain, suffering and death will have an end' (Küng 1977:221). It follows therefore that

In Jesus God's will is already done on earth, all sin is forgiven and all evil overcome; in him here and now ... the kingdom of God has itself dawned - 'in your midst'. [...] He is himself the end. With him the consummation of the world, God's absolute future, has already dawned - even now. With him God is present. (Küng 1977:221)

By conceiving of his death as having a soteriological import, Jesus introduced a new understanding of the role and person of the Messiah, whose expected arrival was supposed to bring the final and decisive moment in the history of Israel (McKnight 2005:62). Furthermore, Christian writers of the first century interpreted Jesus' death in terms of vicarious atonement. ${ }^{6}$ Fuller holds that the words of institution by Jesus (Mt 26:26-28, 1 Cor 11:24) brought together Isaiah 52-53 with Isaiah 42 into a soteriological synthesis that Jesus thought he was fulfilling:

Jesus was not only the prophet of the imminent advent of the eschatological Reign of God, but he also conceived it to be his mission to provide by his death the decisive occasion through and in which God would inaugurate that event whose imminence was the burden of his proclamation. (Fuller 1954:79; cf. also McKnight 2005:62)

5.For example, the sower, who can be identified with Jesus himself, is sowing the seed of God's reign in the hearts of his listeners (cf. Mt 13:1-8; Lk 8:4-8; Mk 4:1-9).

6.The general understanding was that the messianic figure would restore all things to Israel. Besides the military vindication of Israel, which was the substance of popular messianic hope (as distinct from the fuller hope of more select circles from whom the apocalypses emanated), there was no indication of vicarious atonement as in the last Servant song in Isaiah 52:13-53:12 (Gray 1979:294, 198). 
It must be indicated that although Jesus personified the reign of God in his ministry, notably in his association with the religious outcasts of Israel and in his vicarious death, a certain ambiguity or polarity of the 'not yet' and 'but even now' is inherent in his approach to God's reign. Of course, it is easy to say that, whilst Jesus inaugurated the new eschatological reality, its fullness lies in the future. However, what does it actually mean? How can one come to terms with the fact that, though the Messiah came and brought about God's reign, the consummation of this world's order has not taken place and world history simply continues? This ambiguity can be expressed in positive terms, as shown by Küng's question: 'How has Jesus' message remained so inspiring even after his death and although the world has not yet come to an end? Indeed, why did it become inspiring only after his death?' (1977:220). Küng argues that this amazing phenomenon is owing to the paradox of Jesus' cross, which represents a definite end, but at the same time points beyond death (1977:220). One might say that it is only the perspective of the post-resurrection faith that allows for the radical reinterpretation of the categories of the 'not yet' and 'but even now' and thus also of Jesus' eschatological expectation.

\section{Jesus' eschatological mistake: A survey of theological interpretations}

Johannes Weiss argues that Jesus' pronouncements concerning God's reign should be interpreted against the background of Jewish apocalyptic and eschatological expectations, an environment in which Jesus was nurtured and which was highly charged with the hope for God's miraculous intervention (Weiss 1971:129-131; cf. also Lohfink 2014:13-14). Jesus' contemporaries had believed that the historical process was reaching its denouement. A cataclysmic event was about to take place; the God of Israel was on the verge of intervening in human affairs in order to abolish injustice and to make things right on Earth. Jesus also shared in this eschatological hope among his people, and so $\mathrm{He}$ proclaimed the imminent coming of God's reign on Earth, a realm that was to be a golden age for repentant Jews (Sullivan 1988:2-3).

This eschatological view, as held by consistent eschatologists, necessarily leads to the conclusion that Jesus was mistaken in his prophecy. Jesus and his disciples believed and proclaimed that God's reign was about to appear on Earth, yet this expected reign did not come. Dibelius, one of the strong advocates of the erroneous proclamation, posits that it still looks as though a monstrous illusion lies at the basis of the whole mission of Jesus, the illusion of something immediately impending which actually never has come to pass' (Dibelius 1949:70). Instead of God's reign, whose swift arrival Jesus expected, a church filled with Gentiles appeared (Sullivan 1998:24). Thus, according to the radical consistent eschatologists, Jesus must be perceived as a mistaken prophet in error about the major theme of his preaching ministry. As Michael Grant (1977) points out:
Jesus not only believed that God had ordered him to launch his [sic] kingdom on earth, but he also maintained that this process would be completed very soon indeed: that the Day of the Lord was imminent, when God's will would reign everywhere... This proved entirely wrong. The fulfilment did not take place, and has still not taken place. So the whole ministry of Jesus was founded on a mistake. (pp. 193-194)

Albert Schweitzer had understood and interpreted Jesus' saying from Matthew 10:237 to the effect that Jesus did not expect his disciples back in this age and thus was disappointed that they came back without the end of the world having appeared. Because the disciples did return, the prediction was not fulfilled, so it signalled the 'first postponement' of the Parousia (Schweitzer 1998:360; cf. also Kummel 2005:197; McKnight 2005:56-57).

Among the consistent eschatologists, Clayton Sullivan stands out as the one who perhaps developed the theologicalecclesial implications of 'Jesus' mistake' in the most profound and radical way. Sullivan states clearly that 'Jesus' kingdom preaching was predicated on a mistake. His fervent belief that the kingdom would appear on earth within his listeners' lifetime was an error, an illusion, an unfulfilled hope' (Sullivan 1988:64). However, in his final remarks, to support the claim of Jesus being capable of error, Sullivan (1988) alludes to what he perceives as a perennial problem among Christians:

Christians want to refashion this Jesus into a person of their preferences. They prefer a Jesus who never made a mistake and who was thousands of years ahead of his time, they prefer a Jesus who resembles a confident Methodist bishop... But this is not the Jesus we encounter in the Gospels. (p. 118)

Finally, Sullivan ventures a conclusion of far-reaching implications:

There is no a priori reason why the Jesus who experienced historical relativism could not have been transformed by the power of God into the Risen Lord of Christian devotion - the One who lives in the Kerygma and worship of the Church ... God's resurrecting of Jesus, mistaken proclaimer of the Kingdom of God, carries a comforting implication: belief accuracy or doctrinal rectitude is not a prerequisite for divine approval. (Sullivan 1988:118; authors's own italics)

In the same vein, Hans Küng (1977) provocatively asks:

Is not this Jesus ultimately an apocalyptic fanatic? Was he not under an illusion? In a word, was he not mistaken? ... To err is human. And if Jesus of Nazareth was truly man, he could also err. Of course there are some theologians who are more afraid of error in this connection than they are of sin, death, and the devil. (pp. 217-218)

However, Küng qualifies his views by saying that in the context of today's perspective, wherein the apocalyptic horizon has been submerged and the framework of understanding of immediate eschatological expectation rendered obsolete, what is involved in Jesus' immediate not have gone through all the towns of Israel before the Son of Man comes.' 
expectation of the end 'is not so much an error as a timeconditioned, time-bound world view which Jesus shared with his contemporaries' (Küng 1977:220). According to Küng, this biblical narrative about the consummation of God's work on God's creation, precisely as the one on creation itself, is in need of demythologising and contextualising (Küng 1977:218-223).

Patterson (2010:77) prefers, in turn, to speak of Jesus as having second thoughts. Being a real human person, Jesus was not always decisive in his views. Even very remarkable human beings think things over, hedge, try thoughts out, and have second thoughts. Therefore, Jesus too could have had second thoughts.

Needless to say, there are numerous scholars who do not ascribe error to Jesus' 'unrealised expectation' at all. Christian apologists, for instance, reject the view of the consistent eschatologists, since it is at odds with the understanding that the church continues the work of Jesus by teaching what $\mathrm{He}$ taught. Following this line of argument, if Jesus was in error about the central theme of his mission, the concept of God's reign would only be an embarrassment for Christian apologetics and useless for Christian theology (Sullivan 1988:3). An illustration of the apologetic view can be found in Robinson's sarcastic statement: 'Fortunately, we do not have to cope with the problem that Jesus was basically mistaken, but only with the problem that eminent German scholars were basically mistaken' (2011:3218). C.H. Dodd, the leading representative of the realised eschatology, trying to 'save' Jesus from the views of consistent eschatologists, postulates that Jesus' reporters, 'understandably anxious to find his words relevant to their own urgent preoccupations, have given them a twist away from their original intention' (Dodd 1970:123; cf. also Allison 2000:273). The implication is that Jesus made no mistake, but his disciples did; he was just misunderstood. Most exegetes, however, reject such an interpretation.

However, if Jesus was not mistaken, then how can one explain his eschatological expectation - the expectation of the end of the present reality and the beginning of the new one, as apparent especially in Matthew 24:34, Mark 13:29-30, Luke 21:31-32, and Matthew 10:23? It seems that the most promising interpretations of the imminence of Jesus' expectation lie, again, along the middle way, between the extreme views on the nature of God's reign in general and the so-called eschatological mistake in particular. As Küng (1977) points out:

Neither purely futurist 'thoroughgoing' or 'consistent' eschatology (A. Schweitzer), which has nothing to say about the present, nor the purely presentist 'realised' eschatology (C. H. Dodd), which overlooks the outstanding future, represents the whole Jesus. (p. 221)

To such moderate and more subtle interpretations we now turn.

\section{The urgency of Jesus' eschatological expectation reconsidered}

Jesus predicted the coming of God's reign to be so near that it would arrive within the lifetime of his generation. ${ }^{8}$ For him, it was identical with the coming of the Son of Man and the last act of God's royal rule in history (Kummel 2005:198). Therefore, Kummel (2005:190) attempts to reconcile the core biblical texts on Jesus' proclamation of the reign of God and those dealing with the coming of the Son of Man, what he calls the 'pressing imminence of the end', notably Matthew 10:23 and Matthew 24:34. Conceivably, all those texts feature a strong predominance of metaphorical language that suggests the relationship of the returning Jesus to his disciples. The likely meaning of this imagery, Kummel holds, is that the disciples must at all times be ready for the arrival of the Lord. The terms 'to come' and 'to arrive' point already to the expectation of the coming eschatological day, and the coming of the man Jesus who is still living on Earth cannot be mentioned at all except with the 'future' eschatological expectation in mind. Thus, through his teaching Jesus intends to urge preparedness for the day of the Parousia, which may occur at any time and is therefore experienced as something pressing (2005:190ff).

The core text alluding to the imminence of the coming of the Son of Man is the parable of the fig tree (Mt 24:32-35; Mk 13:28-31; Lk 21:29-33). The meaning of the two expressions appearing in this parable, namely 'this generation' and 'all these things', is much debated. In the context of Mark 13:30 and/or Matthew 24:34, 'Truly I tell you, this generation will not pass away until all these things have taken place', 'all these things' designates, according to most exegetes, the whole of the eschatological happenings, including the Parousia (cf. Mk 13:26) and the events leading up to the end (cf. Mk 13:24-25; Mt 24:29; cf. also Kummel 2005:195). This is usually understood as a prediction that the end will come during the lifetime of the present (i.e. Jesus') generation. This interpretation is supported by Jesus' previous declaration in Mark 9:1: 'Truly I tell you, there are some standing here who will not taste death until they see that the kingdom of God has come with power'. However, some scholars, like Schniewind (1933:167) and Busch (1967:133ff), have translated the term 'generation' to denote 'nation'. In this sense, the saying would mean that the Jewish nation would not perish until the end had come. Another translation of 'generation' denotes 'this type'. Consequently, the saying would mean that 'this type, namely the perverse and faithless ... nature of man [sic] will continue to the last day' (Michaelis 1942:30 as quoted in Kummel 2005:195-196).

There are, however, several pieces of synoptic evidence that call both these translations, 'nation' and 'this type', as ambitious and arbitrary as they are, into question. In other New Testament contexts, 'generation' usually indicates distinctly the people of Jesus' time. For example, 'But to what will I compare this generation?' (Mt 11:16) or 'Truly I tell you, 8. Kummel indicates three notable instances to this effect, cf. 2005:190. 
all this will come upon this generation' (Mt 23:36), and so on. In the strength of this evidence, Mark 13:30 and/or Matthew 24:34 cannot be understood - it would seem - otherwise than as referring to 'this generation', which unambiguously predicts the coming of the end during the lifetime of some of the disciples (cf. Mk 9:1). And yet in his famous book The consciousness of Jesus (1972), Jacques Guillet suggested another, more nuanced, understanding of the term in question, an understanding that still resonates with some scholars today (cf. Kummel 2005:196):

The word generation in these formulas has a precise meaning we should not overlook: it is not directly a chronological term signifying the portion of mankind [sic] living on earth in Jesus' day, between 20 and 30 A.D.; it denotes 'this' generation, the portion of mankind [sic] to whom Jesus is speaking, those whom his message has reached. (Guillet 1972:172)

A thoroughgoing biblical exegesis of the core passages (cf. Kummel 2005:1996ff) is one of the ways in which the challenge posed by the urgency of Jesus' eschatological expectation can be faced and dealt with. Others follow different hermeneutic approaches. For example, Conzelmann (1969:11) proposes an ethical view of the imminent expectation as a call to repentance. Radically understood, the expectation of God's reign as having come near must be taken to mean that the human person has no more time left for themselves. It is necessary to respond to God's reign in the present moment, for it is so near that it is no longer possible to ask, 'For how long can I postpone repentance?' or echo young Augustine's cry, 'Grant me chastity and self-control, but please not yet' (1997:198 [VIII:7, 17]).

Although Gerhard Lohfink (2014:14) finds this existential eschatology very appealing, his own approach differs from that of Conzelmann, for it gives due attention to the historical dimension of eschatology. According to Lohfink (2014:13), Jesus' educational work with his disciples and his expectation of the imminent end are intimately and inextricably connected. Jesus spoke of the reign of God not merely as a reality to come someday, in the future. Rather, his preaching had the tone of urgency: God's new world is coming 'now', it is at the door, it is intent on happening 'now', in this very hour. In order for this message to have relevance, Jesus organised a new group of people (disciples) among whom the reign of God could already be a reality. In view of this urgency, Jesus called the poor, the sorrowing, and the hungry 'blessed'. According to Lohfink's view, this does not refer to eternal life in heaven; rather the transformation is about to begin right away. The reign of God is coming 'now'; God's new world no longer lies in the absolutely to-be-awaited future (2014:13-14).

In the same vein, Robinson holds that what happened in Jesus' ministry 'was not just a 'sign' of some future eschatological event. Instead, he talked about the kingdom as something happening now' (Robinson 2011:3218). To support this claim, Robinson argues that Jesus did not pronounce the poor, the hungry, and so on blessed because in the afterlife theirs would be the kingdom, or that they would participate in the eschatological banquet. Instead, Jesus meant God's reign in the here and now (2011:3218-3219).

Lohfink (2014), however, takes that view even further when he claims that

God always acts eschatologically, because - paradoxically - there has been no instant since the creation of the world in which God has not encompassed and sustained this world with divine action, care, mercy, and love that anticipates all. In Jesus, this grace ... reached its ultimate goal. This is the end time. But if the reign of God is still not present in its full abundance, it is not because God is holding it back but because we have not yet grasped it. There is still unbelief everywhere. (p. 15)

The biblical-theological vision of time inherent in the dynamics of God's reign, as captured by Scripture-inTradition, differs significantly from the classical understanding of time that has developed in the West. The latter is based on the concept of linear progression: 'the world is process and ... the course of time is irreversible' (Lohfink 2014:23). In the perspective in which the New Testament conceives time, and in which the New Testament eschatology must be understood,

the end of the world does not come 'at the end', for we are already in the midst of the 'end of the world'. We already live in the end time. Every moment is 'the last hour'. (Lohfink 2014:34)

Clearly, in this specifically paschal vision of time, there may be a distinction, but there is no place for a sharp separation between the 'earthly present' and the 'heavenly future'; there is no radical discontinuity between historical events on the one hand and the eschatological intervention of God on the other hand. Rather there is an uninterrupted continuity in the seeming discontinuity (2014:34). In Lohfink's (2014) words:

God's new creation does not arrive only when the old creation has passed away; it begins already within the old world. In the death and resurrection of Jesus, God's new world has already begun, and in baptism every Christian receives a share in it. (p. 34)

As Vatican II has emphasised, it pleased God to save us not singly, but as a people $(A G, \S 2$ [1965]) - indeed, as a community of creation. This is why Christians find themselves in a history of salvation not as individuals, but ultimately as a church, a family of believers called to solidarity with the rest of humanity as well as the Earth, our sister and mother (LS, $\S 1$ [2015]). As a community of Christ's disciples, the church is to become a prophetic sign of God's eschatological reign. And this does not mean only of something to come, but rather of God's reign, which starts here and now, of a paschal reality that the believers share in and which is constantly having the character of the eschaton:

In our communities, the eschatological salvation of God is constantly approaching us, seeking to change the world. Here, then, we are constantly living in a state of imminent expectation, in a space in which God's promises earnestly seek fulfilment. (Lohfink 2014:16; authors's own italics)

Such an inclusive approach to eschatology may bring to mind the theology of Jürgen Moltmann, who considers eschatology 
to be all embracing, for it is about the faithfulness of the Creator to the creation, about 'a new future for the whole creation' (Bauckham 1999:10; cf. also Moltmann 1996:xi). However, the distinct point made by Lohfink has to do with the responsibility for that future that God chose to share with humanity, and in a special way with the church, which is called to be the sacrament of Christ in the midst of the world.

This leads to the whole new set of theological questions about the universality of eschatological expectation, conceived of not only with regard to Jesus himself, but also with regard to an ecclesial, and indeed cosmic, experience ever since. Some of those questions are reflected upon in the article titled 'How to expect God's reign to come: From Jesus' through the ecclesial to the cosmic body', which has been included in the same volume (Urbaniak \& Otu 2016).

\section{Acknowledgements}

With this article I want to pay tribute to Prof Graham Duncan, my mentor and friend, who keeps showing me what it means to speak truth to power regardless of the consequences and how to be a 'comrade of the kingdom' in a white maledominated academia and ecclesia in the post-apartheid South Africa. Jakub Urbaniak

\section{Competing interests}

The authors declare that they have no financial or personal relationships that may have inappropriately influenced them in writing this article.

We confirm that the above is true.

\section{Authors' contributions}

J.U. and E.O. contributed equally to the conceptualisation and writing of the article. Certain sections of the text are based on E.O.'s master's thesis, written under the supervision of J.U. at St Augustine College of South Africa in 2015. J.U. was responsible for all revisions and prepared the article for submission.

\section{References}

Allison, D.C., 2000, 'The eschatology of Jesus', in J.J. Collins (ed.), Encyclopaedia of apocalypticism. Vol. 1: The origin of apocalypticism in Judaism and Christianity, pp. 267-301, Continuum, New York.

Augustine, 1997, The confessions, transl. M. Boulding, New City Press, Hyde Park, NY. Bauckham, R. (ed.), 1999, God will be all in all: The eschatology of Jürgen Moltmann, T \& T Clark, Edinburg.

Bock, D.L., 2011, 'Faith and the Historical Jesus: Does a confessional position and respect for the Jesus tradition preclude serious historical engagement?', Journal for the Study of the Historical Jesus 9(1), 3-25. http://dx.doi.org/10.1163/1745 51911X601117

Brown, R.E., Donahue. J.R., Senior \& Yarbro, D.A., 2001, 'Aspects of New Testament thought', in R.E. Brown, J.A. Fitzmyer \& R.E. Murphy (eds.), The New Jerome Biblical Commentary, pp. 1354-1381, Theological Publications in India, Bangalore.

Busch, W., 1967, Jesus Unser Schicksal, Schriftenmissions-verlag, Neukirchen-Vluyn.

Conzelmann, H., 1969, An outline of the theology of the New Testament, Harper \& Row, New York.

Deist, F. \& Plessis, I.D., 1981, God and His Kingdom, J.L. van Schaik, Pretoria.

Dibelius, M., 1949, Jesus, Westminster Press, Philadelphia, PA.

Dodd, C.H., 1961, The parables of the Kingdom, Collins Clear-Type Press, London.

Dodd, C.H., 1970, The founder of Christianity, Macmillan, New York.
Dulles, A., 1979, 'Hermeneutical theology', Communio: International Catholic Review 6(1), 16-37.

Forsyth, A.C., 2010, 'The implications for Christology of David Tracy's theological epistemology', Scottish Journal of Theology 63(3), 302-317. http://dx.doi.org/ $10.1017 /$ S0036930610000384

Fuellenbach, J., 2006, The Kingdom of god: The message of Jesus today, Wipf \& Stock, Eugene, Oregon, OR.

Fuller, R.H., 1954, The mission and achievement of Jesus: An examination of the presuppositions of new testament theology, SCM Press, London.

Funk, R.W. \& Hoover, R.W., 1993, The five gospels: The search for the authentic words of Jesus: New translation and commentary, Macmillan, New York.

Grant, M., 1977, Jesus, Weidenfeld and Nicolson, London.

Gray, J., 1979, The biblical doctrine of the reign of God, T \& T Clark, Edinburg, TX.

Guillet, J., 1972, The consciousness of Jesus, Newman Press, New York.

Kaiser, W.C., 2011, Preaching and teaching the last things: Old Testament eschatology for the life of the Church, Baker Academic, Grand Rapids, MI.

Kasper, W., 1976, Jesus the Christ, transl. V. Green, Burns \& Oats, London.

Keener, C.S., 2009, The Historical Jesus of the Gospels, William B. Eerdmans Publishing Company, Grand Rapids, MI.

Kreplin, M., 2011, 'The self understanding of Jesus', in T. Holmen \& S.E. Porter (eds.), Handbook for the study of the Historical Jesus: Individual studies, Vol. 3 , pp. 2473-2515, Brill, Leiden.

Kummel, W.G., 2005, 'The pressing imminence of the end', in J.D.G. Dunn \& S. McKnight (eds.), The Historical Jesus in recent research, pp. 191-200, Eisenbrauns, Winona Lake, IN.

Küng, H., 1977, On being a Christian, Collins, London.

Lohfink, G., 2014, No irrelevant Jesus: On Jesus and the church today, transl. L.M. Maloney, Liturgical Press, Collegeville, MN.

Louis, C.F., 2011, 'Jesus and Apocalypticism', in T. Holmen \& S.E. Porter (eds.) Handbook for the study of the Historical Jesus: Individual studies, Vol. 3 pp. 2877-2909, Brill, Leiden.

Macquarrie, J., 1990, Jesus Christ in modern thought, SCM Press, London.

Maloney, R., 1999, Problems in theology: The human knowledge of Christ, Continuum, London.

McBrien, R.P., 1966, The Church in the thought of Bishop John Robinson, Westminster Press, Philadelphia, PA.

McKnight, S., 2005, Jesus and his death: Historiography, the Historical Jesus, and atonement theory, Baylor University Press, Waco, TX.

Meier, J.P., 2001, 'Jesus', in R.E. Brown et al. (eds.), The New Jerome biblical commentary, pp. 1317-1328, Theological Publications in India, Bangalore.

Michaelis, W., 1942, Der Herr verzieht nicht die Verheissung: Die Aussagen Jesu über die Nähe des Jünsten Tages, Buschhandluner der Evangelischen Gesellschaft, Bern.

Moltmann, J., 1996, The coming of God: Christian eschatology, transl. M. Kohl, SMC Press Ltd, London.

Patterson, S.J., 2010, 'An unanswered question: Apocalyptic expectation and Jesus' Basileia Proclamation', Journal for the Study of the Historical Jesus 8(1), 67-79. http://dx.doi.org/10.1163/174551909X12607965419630

Perrin, N., 1963, The Kingdom of God in the teaching of Jesus, SCM Press, London.

Pope Francis, 2015, 'Laudato Si': On care for our common home' [LS], Encyclical Letter, viewed 12 February 2016, from http://w2.vatican.va/content/francesco/en/ encyclicals/documents/papa-francesco_20150524_enciclica-laudato-si.html

Robinson, J.A.T., 1957, Jesus and His coming, Abingdon Press, New York.

Robinson, J.M., 2011, 'The rise and fall of the "Kingdom of God"', in T. Holmen \& S.E. Porter (eds.). Handbook for the study of the Historical Jesus: Individual studies, Vol. 4, pp. 3201-3220, Brill, Leiden.

Sanders, E.P., 1985, Jesus and Judaism, Fortress Press, Philadelphia, PA.

Schniewind, J., 1933, Das Evangelium nach Markus, Das Neue Testament Deutsch Neue Göttinger Bibelwerk 1, Vandenhoeck \& Ruprecht, Göttingen.

Schwarz, H., 2000, Eschatology, W.B. Eerdmans, Grand Rapids, MI.

Schweitzer, A., 1998, The quest of the Historical Jesus: A critical study of its progress from Reimarus to Wrede, transl. W. Montgomery, Johns Hopkins University Press in association with the Albert Schweitzer Institute, Baltimore, MD.

Sullivan, C., 1988, Rethinking realised eschatology, Mercer University Press, Macon.

Tracy, D., 1981, The analogical imagination: Christian theology and the culture of pluralism, Peeters Press, Louvain.

Tracy, D., 2011, 'God and trinity: Approaching the Christian understanding of revelation', in F.S. Fiorenza \& J.P. Galvin (eds.), Systematic theology: Roman Catholic perspectives, 2 nd ed, pp. 110-129, Fortress Press, Minneapolis, MN.

Vatican II, 1965, Ad Gentes: Decree on the mission activity of the Church [AG], viewed 12 February 2016, from http://www.vatican.va/archive/hist councils/ii vatican council/documents/vat-ii_decree_19651207_ad-gentes_en.html

Urbaniak, J. \& Otu, E., 2016, 'God's reign as a hermeneutic key to Jesus' eschatological expectation', HTS Teologiese Studies/Theological Studies 72(1), a3380, xx pages. http://dx.doi.org/10.4102/hts.v72i1.3380

Weiss, J., 1971, Jesus' proclamation of the Kingdom of God, Fortress Press, Philadelphia, PA.

Whitehouse, W.A., 1953, 'The modern discussion of eschatology', Scottish Journal of Theology Occasional Papers 2, 63-89. 